DIW BERLIN

Discussion

Papers
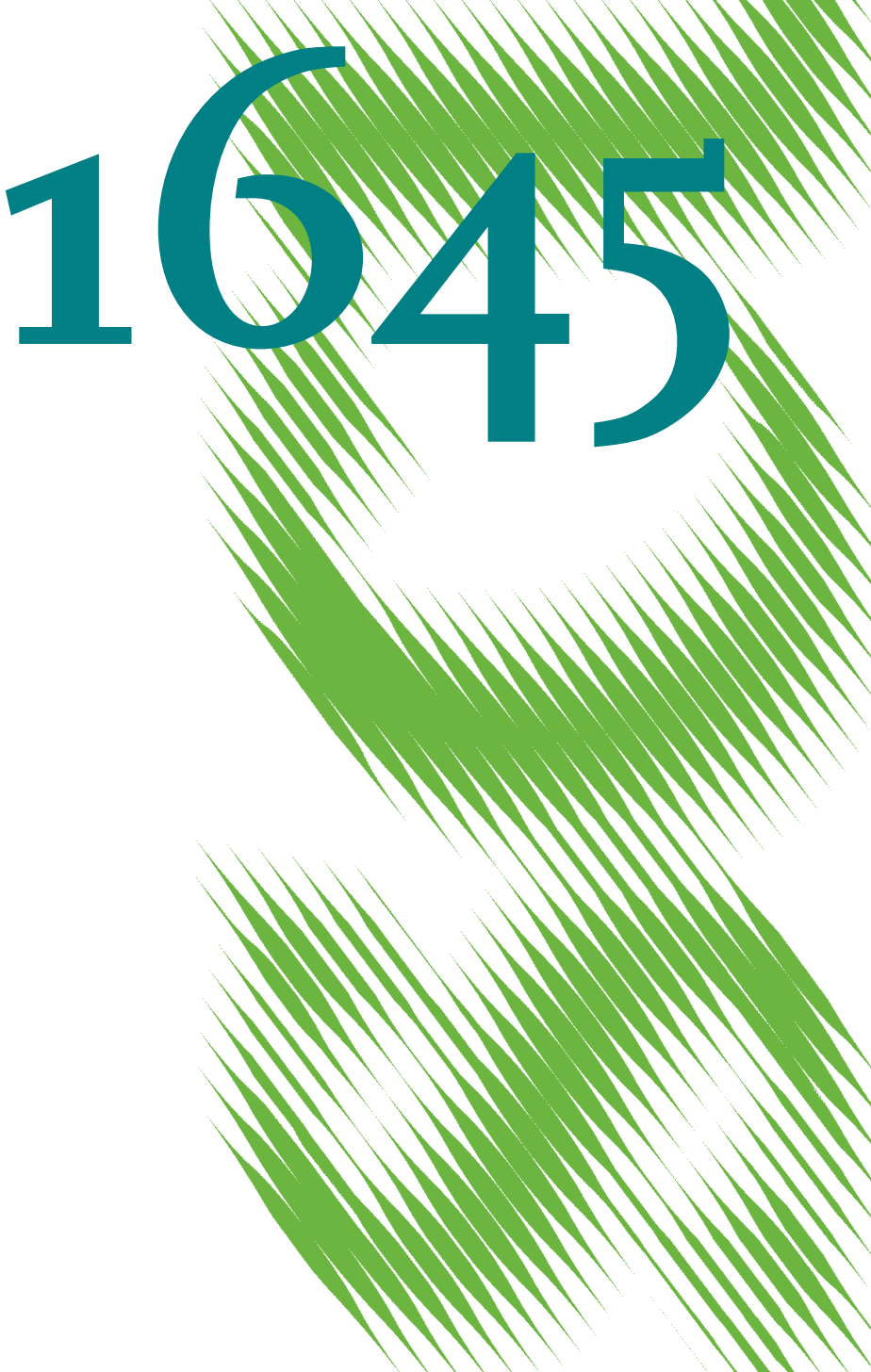

Allais for the Poor:

Relations to Ability, Information

Processing and Risk Attitudes

Tabea Herrmann, Olaf Hübler, Lukas Menkhoff and Ulrich Schmidt 
Opinions expressed in this paper are those of the author(s) and do not necessarily reflect views of the institute.

IMPRESSUM

(C) DIW Berlin, 2017

DIW Berlin

German Institute for Economic Research

Mohrenstr. 58

10117 Berlin

Tel. +49 (30) $89789-0$

Fax +49 (30) $89789-200$

http://www.diw.de

ISSN electronic edition 1619-4535

Papers can be downloaded free of charge from the DIW Berlin website:

http://www.diw.de/discussionpapers

Discussion Papers of DIW Berlin are indexed in RePEc and SSRN:

http://ideas.repec.org/s/diw/diwwpp.html

http://www.ssrn.com/link/DIW-Berlin-German-Inst-Econ-Res.html 


\title{
Allais for the Poor: Relations to Ability, Information Processing and Risk Attitudes
}

\author{
Tabea Herrmann, Olaf Hübler, Lukas Menkhoff and Ulrich Schmidt
}

\begin{abstract}
This paper complements evidence on the Allais paradox from advanced countries and educated people by a novel investigation in a poor rural area. The share of Allais-type behavior is indeed high and related to characteristics of "lacking ability", such as poor education, unemployment, and little financial sophistication. Based on prospective reference theory, we extend these characteristics by biased processing of probabilistic information. Finally, we reveal that Allaistype behavior is linked to risk-related characteristics, such as risk tolerance and optimism. This indicates a potential problem as exactly the more dynamic among the poor tend to make inconsistent decisions under uncertainty.
\end{abstract}

JEL-Classification: D 81 (decision making under risk and uncertainty), D 03 (behavioral microeconomics: underlying principles), O 10 (general economic development)

Keywords: $\quad$ Field experiments; Allais paradox; socio-demographic characteristics; prospective reference theory; first order stochastic dominance; risk attitude; optimism

February 2017 (11.16)

We thank Manel Baucells, Michael H. Birnbaum, Ferdinand M. Vieider, W. Kip Viscusi (the editor) and an anonymous referee for helpful comments on an earlier version of this paper. Financial support by the German Research Foundation (DFG, grant RTG 1723) is gratefully acknowledged.

Tabea Herrmann, Leibniz University of Hannover, Königsworther Platz 1, D-30167 Hannover, Germany; herrmann@glad.uni-hannover.de.

Olaf Hübler, Leibniz University Hannover, Königsworther Platz 1, D-30167 Hannover, Germany; huebler@ewifo.uni-hannover.de.

Lukas Menkhoff, German Institute for Economic Research (DIW Berlin), D-10108 Berlin, Germany, Humboldt-University Berlin and Leibniz University of Hannover; lmenkhoff@diw.de.

Ulrich Schmidt (corresponding author), Kiel Institute for the World Economy, University of Johannesburg and University of Kiel, Department of Economics, Olshausenstr.40, D-24118 Kiel, Germany; uschmidt@bwl.uni-kiel.de. 


\section{Allais for the Poor: \\ Relations to Ability, Information Processing and Risk Attitudes}

\section{Introduction}

Beginning with the famous paradoxes of Allais (1953), the experimental literature has gathered abundant evidence that expected utility theory (EUT) does not provide an accurate description of individual choice behavior under risk. Whereas the existence of the Allais paradox has been well documented there are still competing explanations about the origins of this behavior. One line of studies argues that violation of EUT is related to less ability in understanding the often complex decisions to be made (e.g. Levy, 2008; Burks et al., 2009; Benjamin et al., 2013; Choi et al., 2014). Consequently, "less able" people should show more Allais-type behavior than others.

The potential relation between ability and Allais-type behavior is interesting for understanding the Allais paradox but it is also interesting because of possible implications. Allais-type behavior is a deviation from strictly rational (EUT-type) behavior by making inconsistent decisions and thus may indicate some limitation in the quality of decisions. If these limitations handicap in particular "less able" people, this would contribute to cementing their inferior socio-economic position. Accordingly developing countries with lowly educated people, such as the rural areas of Northeast Thailand, would be strongly affected.

However, there is hardly any evidence on the relation between Allais-type behavior and the ability of individuals. The main systematic study in this direction we are aware of is Huck and Müller (2012) examining a representative sample of the Dutch population. There, Allais-type behavior is more common among less educated, unemployed, lower income and financially less sophisticated people, supporting the above mentioned "ability"-hypothesis. These empirical relations strengthen our motivation to analyze the Allais paradox in a sample of a relatively poor and lowly educated population (see Charness and Viceisza, 2015).

We run an Allais-experiment with poor individuals for whom we also get sociodemographic characteristics. This allows replicating the Huck and Müller approach with a sample of poor individuals. Our expectations are finding a relatively high level of EUT-violations (compared to people from advanced economies) and still confirming the ability hypothesis in the cross-section of observations. As the power of standard socio-demographic characteristics in 
explaining Allais-type behavior is somewhat limited we aim for extending the set of individual characteristics. We hypothesize that further relevant characteristics may be found among those which are known to influence decision making under uncertainty.

We consider two kinds of characteristics: first, a variable indicating a rather specific ability in handling the Allais task where ability is related to correct processing of probability information; we label this as a math-related ability. Such specific ability may complement the more general ability examined so far (such as educational level), and we consider here the response to an experiment testing for possible violation of "first-order stochastic dominance" (FSD; see Birnbaum, 1997). The selection of the FSD-experiment is motivated by a novel theoretical contribution of this paper which is based on prospective reference theory (Viscusi, 1989). Prospective reference theory (PRT) provides a modelling of biased processing of probability information which has been regularly observed in empirical studies (Viscusi and O'Connor, 1984; Viscusi, 1985; Viscusi et al., 1987). Our analysis is the first to show that if Allais-type behavior is caused by biased processing of probability information, it should be positively correlated to violations of FSD under PRT. We believe that in particular for lowly educated people as in our sample biased processing of probabilities can be an important origin of Allais-type behavior. At the same time, FSD-violations clearly document disadvantageous decision making under risk which may contribute to development traps.

As second novel kind of characteristics we consider two variables indicating risk-related attitude which may shape the economic decisions of our subjects in the real world. First, we consider a measure about the risk attitude of individuals since it is not obvious ex ante whether more or less risky individuals tend to show Allais-type behavior. Second, we test whether the optimism (mood) of individuals plays a role. If so, the relation to Allais-type behavior should be the same as for risk attitude, i.e. risk tolerant and optimistic individuals are expected to show the same tendency towards EUT-violation.

In our experiments, we test for Allais-type behavior using a sample of 778 individuals from rural Northeastern Thailand. This is Thailand's poorest region with a median per capita income of about 1,500 PPP-USD per year. Lack of development is also indicated by an average of 4 to 6 years of schooling of the adult population.

Overall, we get four findings. First, about $54 \%$ of the individuals violate independence in the Allais paradox which is a violation rate at the upper bound of earlier studies. This high level seems remarkable since we take three measures in the experimental design to avoid an upward 
bias in EUT-violation rates: (1) we keep the lotteries simple, especially when compared to the original setting (Allais, 1953). This should facilitate consistent decision making in general (e.g. Levy, 2008). (2) We avoid extremely high (hypothetical) payoffs as in the original experiment since they have been shown to lead to more Allais-type behavior (e.g. Huck and Müller, 2012). (3) We implement incentive-compatible pay-offs of considerable size in order to overcome often voiced concerns that otherwise decisions may be less carefully made (Holt and Laury, 2002) although the evidence for this concern is often not very strong (Camerer and Hogarth, 1999).

As second contribution we analyze whether the socio-demographic relations with Allaistype behavior established by Huck and Müller (2012) hold among a poor rural population. We also find that individuals with higher education, more experience in terms of relevant occupational activities (employment status) and in terms of financial sophistication tend to show less Allais-type behavior. We take this as evidence for more able people to show less Allais-type behavior, as argued for example by Levy (2008).

Third, we extend the ability characteristics by a math-related variable, i.e. biased processing of probability information. Based on our theoretical analysis we address this bias by analyzing FSD and find that behavior in this task is related to Allais-type behavior in the expected way: consistent with PRT, less violations of FSD occur together with less inconsistent decisions in the Allais task. Interestingly, the responses to this math-related variable are very different from individuals' cognitive ability.

Fourth, we find that measures of risk-related behavior provide further explanatory power in the cross-section: Allais-type behavior is more often observed among individuals with more risktolerance and optimism.

The implications of these findings for development are not good: the relation between various ability variables and Allais-type behavior may be seen as another contribution to the often lamented development traps or vicious cycles. Even worse, however, is the positive relation of Allais-type behavior to risk-tolerance and optimism, i.e. to the particularly dynamic people. It may reinforce development problems that exactly these people are prone to making inconsistent decisions under uncertainty.

Our research is related to the many previous studies of Allais-behavior, documenting its prevalence (Allais and Hagen, 1979; Conlisk, 1989; Birnbaum, 1999). However, evidence stems mainly from laboratory experiments with students. Our study is different in that we combine household surveys with field experiments, such as Tanaka et al. (2010) or Dohmen et al. (2011). 
In this respect, the study of Huck and Müller (2012) is the first (and so far only one) to run Allais experiments with a representative sample of about 1,500 Dutch individuals. Also in line with the "ability" hypothesis, Finkelshtain and Feinerman (1997) show with 180 Israeli farmers that Allais-type behavior is related to less education and experience. However, different from our research, these studies are conducted in advanced economies and they do not consider math- or risk-related individual characteristics.

The remaining paper is structured in six sections: Section 2 derives the hypothesis to be tested from the extant literature and describes the experiments. Section 3 presents the sample from rural Thailand. Section 4 provides the experimental outcomes and the relation of Allais-type behavior with socio-demographic variables and risk characteristics. Several robustness analyses are documented in Section 5 and conclusions are discussed in Section 6.

\section{Hypotheses and experimental design}

In this section we present the experimental design and the theoretical background of our analysis. Based on the reasoning provided in the introductory section we derive four concrete hypotheses which we aim to test in our study.

Allais experiment. We ran an incentivized Allais experiment in the form of a standard common ratio effect (Allais, 1953; Kahneman and Tversky, 1979). Stimuli in the experiment were presented as bags, each of which containing 100 cards with different payoffs written on them. Participants got to draw one card from the bag that corresponded to their choice in the experiment and received the respective amount in the local currency Baht (Bt.). The common ratio effect consists of two choice problems:

\section{Choice 1:}

Bag A

100 cards to win Bt 75
Bag B

80 cards to win $\mathrm{Bt} 100$

20 cards to win Bt 0

\section{Choice 2:}

Bag C

25 cards to win $\mathrm{Bt} 75$

75 cards to win Bt 0
Bag D

20 cards to win Bt 100

80 cards to win Bt 0 
We used the standard "random lottery incentive mechanism", i.e. subjects were told that only one of the two choice problems would be paid out which was determined by a coin flip (for further details, see Appendix A). Consider an expected utility maximizer with von NeumannMorgenstern utility function $\mathrm{u}(\bullet)$. As the utility function in EUT is unique up to positive linear transformation we can normalize it without loss of generality such that $\mathrm{u}(0)=0$. Then Bag A will be preferred to Bag B if $u(75)>0.8 u(100)$. Dividing this inequality by four yields $0.25 u(75)>$ $0.2 \mathrm{u}(100)$ which is precisely the condition for Bag C being preferred to Bag D. In other word, EU demands that a subject either chooses $\mathrm{A}$ and $\mathrm{C}$ or B and D. Choices of A and D or B and C in contrast violate EUT. Abundant evidence has been gathered that many people violate EU in this design. As the violating choice pattern $\mathrm{A}$ and $\mathrm{D}$ is much more frequently observed than the pattern $\mathrm{B}$ and $\mathrm{C}$, these violations are systematic and, therefore, not likely caused by random error (Conlisk, 1989).

Experiment on stochastic dominance. In the incentivized experiment on first-order stochastic dominance in the design of Birnbaum (1997) subjects had to tackle the following choice problem:

\section{Choice 3:}
Bag E
Bag F
90 cards to win $\mathrm{Bt} 96$
85 cards to win Bt 96
5 cards to win Bt 14
5 cards to win Bt 90
5 cards to win Bt 12
10 cards to win Bt 12

This problem is easily conceived if we consider the underlying baseline gamble which offers a $90 \%$ chance of winning $96 \mathrm{Bt}$ and a $10 \%$ chance of winning $12 \mathrm{Bt}$. Bag E is constructed from this baseline gamble by splitting up the $10 \%$ chance of the worse prize into two events (with $5 \%$ probability each) and making the gamble slightly better, i.e. by replacing one of the outcomes with $14 \mathrm{Bt}$. Consequently, Bag E dominates the baseline gamble. Bag F is constructed from the baseline gamble by splitting up the $90 \%$ chance of the better outcome into two events (with $85 \%$ and 5\% probability) and making the gamble slightly worse by replacing $96 \mathrm{Bt}$ in the split event with $5 \%$ probability by $90 \mathrm{Bt}$. Therefore, Bag $\mathrm{F}$ is dominated by the baseline gamble and also dominated by Bag E, as first-order stochastic dominance is transitive. Consistency with firstorder stochastic dominance is one of the most fundamental criterions of rationality in decision 
theory. Nevertheless, Birnbaum (2004a, b) observed in a design identical to ours violation rates of $70 \%$ for undergraduates and $50 \%$ for doctorates.

Theoretical predictions. In the most prominent version of PRT the utility of a gamble $\mathrm{G}=$ $\left(\mathrm{x}_{1}, \mathrm{p}_{1}, \mathrm{x}_{2}, \mathrm{p}_{2} ; \ldots ; \mathrm{x}_{\mathrm{n}}, \mathrm{p}_{\mathrm{n}}\right)$ where you win the monetary amount $\mathrm{x}_{\mathrm{i}}$ with probability $\mathrm{p}_{\mathrm{i}}$ is given by

$$
\mathrm{V}(\mathrm{G})=\sum_{\mathrm{i}=1}^{\mathrm{n}} \mathrm{u}\left(\mathrm{x}_{\mathrm{i}}\right) \mathrm{w}\left(\mathrm{p}_{\mathrm{i}}\right) \text { with } \mathrm{w}\left(\mathrm{p}_{\mathrm{i}}\right)=\frac{\gamma\left(\frac{1}{\mathrm{n}}\right)+\xi \mathrm{p}_{\mathrm{i}}}{\gamma^{+} \xi} \text { for } 0<\mathrm{p}_{\mathrm{i}}<1, \mathrm{w}(0)=0 \text {, and } \mathrm{w}(1)=1
$$

In this representation $\mathrm{u}$ is a standard von Neumann-Morgenstern utility function as in EUT and $\mathrm{w}\left(\mathrm{p}_{\mathrm{i}}\right)$ is the weight of an outcome with probability $\mathrm{p}_{\mathrm{i}}$. The transformation of probabilities by $\mathrm{w}$ represents a biased processing of risk information which is in line with empirical observations (Viscusi and O'Connor, 1984; Viscusi, 1985; Viscusi et al., 1987). To interpret the weight one can think of a subject who has not full confidence in the stated probabilities and has a symmetric prior (i.e. $1 / \mathrm{n}$ ) where $\gamma(\xi)$ represents the informational content of the prior (stated probabilities). Then Bayesian updating leads precisely to the weights defined in (1).

In order to see how biased processing of probability information in PRT implies violations of dominance, we assume for convenience that the utility function is linear (i.e. $u(x)=x)$ and define $\gamma^{*}=\gamma /(\gamma+\xi)$ and $\xi^{*}=\xi /(\gamma+\xi)$. Then a subject will prefer Bag F to Bag E if $\gamma^{*}(96+90$ $+12) / 3+\xi^{*}\left(0.85^{*} 96+0.05^{*} 90+0.1^{*} 12\right)>\gamma^{*}(96++14+12) / 3+\xi^{*}\left(0.9 * 96+0.05^{*} 14+\right.$ $0.05 * 12)$ which implies $66 \gamma^{*}+87.3 \xi^{*}>40.7 \gamma^{*}+87.7 \xi^{*}$, i.e. $\gamma^{*}>0.016 \xi^{*}$. Hence, already an extremely small bias towards the symmetric prior implies violations of dominance.

PRT is also able to accommodate the common ratio effect. Easy calculations reveal that Bag A is preferred to B if $\gamma^{*}>0.2 \xi^{*}$ while Bag D is for all non-negative $\gamma^{*}$ and $\xi^{*}$ preferred to Bag C. Hence $\gamma^{*}>0.2 \xi^{*}$ implies the typical pattern of violation reported in the experimental literature. This condition is also sufficient for subjects violating dominance. Consequently, according to PRT, violations of dominance and Allais-type behavior should be positively correlated.

Hypotheses. Given our theoretical analysis and the state of the literature shortly sketched in the introductory section, we derive four hypotheses to be tested: (H1) The degree of violation of EUT, i.e. the observation of Allais-type behavior, is relatively higher among a poor population compared to results from advanced economies. (H2) The socio-demographic correlates of Allaistype behavior found by Huck and Müller (2012) are expected to be replicated in our completely 
different sample too. The overall theme of this hypothesis is the relation of lacking ability to inconsistent decision making, such as Allais-type behavior. (H3) Extending the so far considered individual ability characteristics we hypothesize that part of EUT-violation may be caused by biased processing of probability information. According to PRT, this implies that Allais-type behavior is more frequent among subjects violating dominance. (H4) Finally, reaching beyond individual ability, we expect that behavior in the Allais experiment may be also related to behavior regarding other decisions under uncertainty. In this respect we examine risk attitude and optimism.

Procedure of the experiments. The experiments are part of a regular household survey. Besides socio-demographic information, the survey asks, among others, for risk attitude and optimism and includes, towards its end, our two experiments. Each survey was conducted individually at the household's dwelling.

Both experiments were implemented following established standards as we will argue in detail below. The Allais experiment was always conducted first and alternatives of choices were kept in the same order. As a result, the experiments were easier to administer in the field. Moreover, there does not seem to be a disadvantage as Huck and Müller (2012) show that varying the order of the Allais experiment has no effect on experimental outcomes. After the two decisions in the Allais experiment were made, the experimenter threw a coin to determine the relevant choice problem and then the subject could draw a card from the chosen bag. When making choices in the Allais experiment, subjects had neither information about whether a further choice problem will be presented to them nor about its kind, i.e. the FSD experiment. Note that irrespective of the outcome in the Allais experiment it is always optimal to choose Bag $\mathrm{E}$ in the FSD experiment. After making a choice in this experiment and drawing one card from the preferred bag, subjects received their final payment (i.e. the sum of both cards drawn). The expected average amount is $136 \mathrm{Bt}$, which corresponds to roughly 4 US-dollar, i.e. it is equal to about half a day's wage or more of an unskilled worker. This amount should ensure that financial incentives are effective and participants make careful decisions.

Measure of risk attitude. We use two variables to measure risk attitude which have been used, for example, by Dohmen et al. (2011). The reliability of these simple survey items in comparison with established experimental measures has been demonstrated for Germany by Dohmen et al. (2011), for the Northeast of Thailand by Hardeweg et al. (2013), and for small samples in 30 countries by Vieider et al. (2015). This shows the usefulness of these items on risk 
attitudes in our context. The first item is based on the question "How willing are you to take risks, in general?" Respondents rate their willingness on an 11-point scale from 0 to 10 . An individual gets a value of 0 if she is unwilling to take risk, whereas being fully prepared to take risk gets a value of 10 .

In addition to this general measure of risk attitude we also use a more domain-specific hypothetical investment game question (see also Barsky et al., 1997). The question to be answered is as follows: "Imagine you just won 100000 Baht in a lottery and you can invest this money in a business. There is a $50 \%$ chance that the business is successful. If the business is successful you double the amount invested after one year. If it is not successful you will lose half the amount you invested. What fraction of the 100000 Baht would you invest in the business?" The answer, i.e. the fraction being invested (a share between $0 \%$ and $100 \%$ ), provides a measure of risk tolerance. In the later regressions we take this value in PPP US-dollar.

Measure of optimism. It is known that risk-related behavior is influenced by an individual's degree of optimism (see, e.g., Puri and Robinson, 2007). Therefore we infer the degree of optimism by a simple question: "Do you think you in person will be better off next year?" Answers range from "much better off", "better off', "the same", "worse off” to "much worse off'. The coding of these answers is aggregated as 1 (better off and much better off) versus 0 (other responses). Accordingly, this variable provides a rough measure of optimism.

\section{The sample in rural Thailand}

A major advantage of this study is the availability of both socio-demographic data provided by a household survey and experimental data on decision behavior of the same individuals.

Household survey. The household survey, conducted in April and May 2010, is the basis for our research and forms part of a large research project comprising several waves of data collection (for more information, see Klasen and Waibel, 2013). Applying a three-stage sampling procedure, we have a sample that is representative for the rural population in the selected Northeastern Thai provinces. We have data on about 900 households from Ubon Ratchathani, the province where the field experiments were conducted. Household heads were interviewed in the majority of cases as our aim was to access reliable information on the entire household. As a consequence, households are representative for the rural parts of this province but the individual respondents are not, as they are relatively old compared to the overall population, for example. 
The household questionnaire provides socio-demographic information about the respondent and the household. Following the study of Huck and Müller (2012), we choose from the set of available information four groups of socio-demographic variables which may affect decision behavior: (1) basic personal information, such as education, (2) information about the main occupation possibly indicating experience with risky decisions, (3) information about the economic situation, primarily captured by household income, and (4) information about individuals' financial behavior. Extending these variables, we also consider one variables addressing math-related behavior and two variables addressing risk-related behavior.

Socio-demographic variables. The personal information comprises respondents' sex, age and years of schooling. Summary statistics of the sample are given in Table 1 . The sample is somewhat biased towards women with more than $60 \%$. Respondents are on average about 52 years old and thus somewhat older compared to the population as a whole which is due to migration and our ambition to contact household heads. The main analyses are conducted with age measured by age groups which allows for non-linear effects; as further motivation for this procedure, we aim for replicating Huck and Müller (2012) and they use the same age groups. The years of schooling are widely scattered with clear peaks at four and six years (representing primary education) which were the minimum years of schooling some decades ago. Again we work with educational groups, representing primary education (from zero up to 6 years of schooling), lower and upper secondary education and university degree. Next, we consider the occupational status of respondents, distinguishing between wage-earners, self-employed, unemployed, working in the household (mainly housewives) and others. In particular, farmers belong to "others", which serves as reference category. The intuition here is that the type of occupational activity might influence familiarity with risky decisions similar to the Allais-case. Regarding the economic status, we consider annual household income in three groups, taking care of potential non-linearity. Thus the dummy variable "middle income class" represents households whose log income is in the inner 50\%-interval of all households. In robustness exercises we also experiment with continuous log income, log income per capita and consumption per capita which is a reasonable welfare measure in the context of a poor rural population (Hentschel and Lanjouw, 1996). Finally, the consideration of financial behavior is proxied by the number of savings accounts a household uses; this variable includes accounts at semi-formal financial institutions and multiple accounts at the same institution. This variable is seen as a measure of sophistication and diversification, replacing the variable "(financial) assets" 
used by Huck and Müller (2012). Their reliance on a "savings account" as indicator of inferior sophistication does not apply to Thailand because basically all household use such an account.

Math-related characteristic. We rely on a math-related characteristic as described and motivated in Section 2. This characteristic is the processing of probability information assessed by the response to the first-order stochastic dominance experiment. In the robustness part we also use numeracy (mathscore) and a memory measure of cognitive ability. However, these two variables are available for a sub-population only.

Risk-related characteristics. We use two risk-related variables because the Allais experiment itself contains a decision under uncertainty and thus may be influenced by a person's attitude towards risk. These risk-related variables have been introduced in Section 2 above, because they are new in this literature. As a minimum, they can be interpreted as control variables to check robustness of the more standard socio-demographic relations. However, the risk-related variables can be also seen as independent correlates of Allais-type behavior which would establish a new relation to the best of our knowledge.

Balanced sample. For the data analysis, we use a balanced sample where observations with missing information are excluded. The final sample has 778 observations and is $15 \%$ smaller compared to the original sample. The composition of excluded observations is somewhat different compared to the restricted sample. As Table 1 shows, the excluded individuals are on average more often in the highest age category ( $\geq 65$ years), less educated, have lower income, fewer savings accounts, are less risk tolerant and less optimistic; most characteristics seem likely to be a consequence of the exclusion of the really elderly.

\section{Results}

This section describes results of the four hypotheses being tested: first, we report the outcome of the Allais experiment (Section 4.1), then its relations to standard socio-demographic correlates (Section 4.2), its relations to the math-specific correlate (Section 4.3) and finally relations between Allais-type behavior and variables informing about risk-related characteristics (Section 4.4).

\subsection{Results on the Allais experiment}

Our results of the Allais-experiment largely fit into earlier literature as Allais-type behavior (i.e. choosing either $\mathrm{AD}$ or $\mathrm{BC}$ ) is shown by a considerable share of participants and violations of 
EUT reveal the usual systematic pattern. Exact numbers are given in Table 2 which shows the relative frequencies of choices. A test shows that these frequencies differ significantly from each other (see Table 2), rejecting the concern of accidental, noisy responses.

The share of individuals showing Allais-type behavior is $53.7 \%$ and thus rather large. This can be regarded as empirical support for hypothesis 1 . The share is even larger with $56.8 \%$ for the full sample (915 individuals), indicating that we indeed exclude less educated, less optimistic etc. kind of people from our balanced sample. As we further see from Table 2, consistent with findings in previous studies, the occurrence of the Allais-type behavior is systematic such that the combination $\mathrm{AD}(37.4 \%)$ is much more frequent than the combination $\mathrm{BC}(16.3 \%)$. According to the test of Conlisk (1989), this pattern is significant $(\mathrm{p}<0.01)$. All this indicates reliability of our data so that we continue the analysis.

\subsection{Socio-demographic correlates}

Next, we analyze the role of individual socio-demographic characteristics in explaining the Allais-type behavior. Table 3 gives in column (1) results of probit regressions of sociodemographic characteristics on the experimental outcome. The latter is measured as binary variable with 1 indicating the occurrence of Allais-type behavior. The socio-demographic variables are chosen and coded in a way to allow replicating the approach by Huck and Müller (2012).

Discussing variables in the order of their benchmark study, we see that gender and age have no relation to Allais-type behavior. By contrast, there is a link of better education - university and tentatively higher secondary education - to less inconsistent decisions. Regarding occupational status, unemployed show more Allais-type behavior, and housewives too, although to a smaller extent. Different from expectations, income has no relation to Allais-type behavior (and this holds for various definitions of income as demonstrated in the robustness part). Finally, our measure of financial sophistication, i.e. the use of several bank accounts (i.e. forms of savings accounts), is linked to less inconsistent decisions. All of these relations hold when we include only significant RHS-variables in the regression (see column 2). In sum, we get a pseudo $\mathrm{R}^{2}$ of 0.06 and confirm three of the four statistically significant variables of the benchmark study by Huck and Müller (2012). However, we do not find a relation regarding income. In the Huck and Müller (2012) sample, income has a negative coefficient, suggesting that it captures some form of ability (which generates high income), leading to less Allais-type behavior. In our sample the 
coefficient is positive and insignificant or weakly significant, indicating that different influences are driving it; we come back to this issue in Section 4.4 below.

\subsection{Math-related correlate}

In the next step we add the math-specific variable to our benchmark specification as introduced above. Thus, column (3) in Table 3 is specified as column (1) plus adding FSD as new variable, i.e. a violation of first-order stochastic dominance in our experiment. We see that the respective coefficient has the expected positive sign, that it is statistically significant and that it improves estimation with a pseudo $\mathrm{R}^{2}$ of 0.07 .

We learn from this regression that not just general ability variables, such as education, help to understand Allais-type behavior but also the math-specific variable contributes to our understanding.

\subsection{Risk-related correlates}

As last extension we examine the possible relation of risk-related variables to Allais-type behavior. We proceed similarly to the steps documented before (see Table 3). Thus, the first column (1) in Table 4 shows the baseline regression (i.e. column 1 from Table 3 ) plus our preferred measure of risk attitude. We see that the general willingness to take risk is positively related to Allais-type behavior. Next, we keep the specification but replace the general measure of risk attitude by the more domain-specific measure of a hypothetical investment question (see column 2). Again, the variable has the expected sign, although it is only weakly significant. In column (3) we add the measure of optimism to the baseline specification and see that optimism is strongly related to Allais-type behavior.

Finally, we put the three new variables together into a joint specification which is presented in column (4). In this specification we get the highest explanatory power with a pseudo $\mathrm{R}^{2}$ of 0.09. Moreover, the general measure of risk attitude remains significant, whereas the specific measure turns insignificant which may have been expected from columns (1) and (2). Interestingly, and despite estimating here the largest number of variables, the formerly significant coefficients keep sign and significance. This indicates that the three variable groups of interest, i.e. the conventional socio-demographic, the math-related and the risk-related characteristics are indeed different from each other. Whereas they all represent some kind of ability, the almost 
unchanged coefficient signs show that these variables each provide an independent contribution to understanding Allais-type behavior.

Regarding the conventional socio-demographic characteristics they are understood as indicators of a quite general ability, either rooted in intellectual competence or competence rather learned from experience. The math-related characteristic indicates that also this specific ability plays a role when making decisions in the number-based Allais setting. Finally, the risk-related characteristics require some discussion because there is no clear ex ante hypothesis regarding the sign of the coefficients (except for the identity of their signs). One interpretation may see the signs as an indicator of ability, e.g. the ability of carefulness. This is because risk tolerant and optimistic individuals may tend to make quicker and less thoughtful decisions and thus they end up more often with showing Allais-type behavior, independent of their further abilities. Another interpretation may see the signs as indicator of how people perceive the risky choices. The move from A to D certainly involves some willingness to take risk and may be perceived by some people as such; then it would be related to risk tolerance.

\section{$5 \quad$ Further results and robustness}

In this section we report further results on robustness analyses which largely support our main findings. The following analyses are conducted: (1) We estimate the above models again using continuous instead of categorical variables, (2) the income measure used is substituted by plausible alternatives, (3) we analyze the baseline model separately depending on the kind of EUT-violation, (4) we control for individual cognitive ability in a reduced sample, (5) alternative estimation methods for coefficients and standard errors are applied and (6) finally we show a few correlations between Allais-type behavior and behavior of the same people, cautiously indicating that Allais-type behavior leads to suboptimal decisions.

Modified age and education definitions. The model specifications reported so far are mainly based on categorical variables of age and education in order to replicate the Huck and Müller (2012) study. If one aims for parsimonious regression specifications, however, a continuous definition of these variables may be of interest. Thus, we use years of age and of schooling as alternative variable definition. The result in Table 5, column (1) shows that this is not very important but that explanatory power is somewhat worse, indicating that the relation is non-linear. Thus, we stick to the categorical approach. 
Income measures. We run further analyses where we substitute our classified measure of per capita income by the simple logarithm of household income, per capita income or per capita consumption. Results in columns (2) to (4) in Table 5 show: these modifications do not change overall estimation quality and coefficient sizes much. Interestingly, the income measures keep their positive coefficient sign and the log income per capita even turns marginally significant. In combination with the positive coefficients on risk measures this may suggest that the income coefficient picks up characteristics which are related to risk taking; the latter is related to higher income and indeed, adding risk variables to the baseline specification reduces the income coefficient (see Table 3, column 1 and Table 4, column 1).

Kind of EUT-violation. In Section 4 we document which variables may be related to Allais-type behavior in general. Now, we split up Allais-type behavior, i.e. the choice of the decisions $\mathrm{AD}$ and $\mathrm{BC}$ in the Allais experiment (see Table 2). We do this in order to see whether Allais-type behavior is more associated to general characteristics of individuals, such as their general ability (e.g. cognitive ability), or whether there are specific relations between the kind of Allais-type behavior and specific characteristics.

Table 6 reproduces in column (1) the baseline regression, shown in column (4) of Table 4. Next, column 2 shows the result for the choice AD and column (3) shows the result for the choice BC. Regarding most RHS-variables there is no obvious difference in both new specifications: e.g., gender remains insignificant, unemployed keeps sign and significance, housewife keeps sign but loses significance in column (3), the coefficients on savings accounts become smaller and thus lose significance, whereas the coefficients on the optimism variable also become smaller but remain significant.

However, there are also a few marked differences between columns (2) and (3): the choice of $\mathrm{AD}$ is related to younger, less educated individuals with FSD-violation which again supports PRT. In short, this fits roughly to the overall regression in column (1). By contrast, choice BC is associated to older individuals willing to take more risk. Thus, there is some difference, cautiously supporting he notion that our results are neither due to noise nor due to a general ability driven all kinds of Allais-type behavior.

Cognitive abilities. The FSD-task can be interpreted differently, either as a sign of perception of individuals or as a sign of cognitive ability. It seems thus important trying to control for cognitive ability (see, e.g., Burks et al., 2009). Similarly, it has been argued that risk taking is positively related to cognitive ability (see Benjamin et al., 2013), although this has been 
challenged by Andersson et al. (2016). We do explicitly control for cognitive ability here but the price is that we have to work with a much smaller sample. Whereas our main data come from 2010, items about cognitive ability were compiled in 2013 with the same households. However, the specific person in the household responding is often different so that sticking to exactly the same persons reduces sample size from 778 to 476 .

There are two measures addressing aspects of cognitive ability (inspired by Christelis et al., 2010), one is a measure of numeracy and the other one is a measure of memory and verbal ability (see Appendix B for full description). The numeracy measure has six tasks, the first four are taken from Cole et al. (2011), the two others are intended to represent tasks 2 and 3 from a standard survey used by Christelis et al. (2010). Regarding the measure of verbal activity, this has been used, among others, by Christelis et al. (2010) or Dohmen et al. (2010). We find that both dimensions of cognitive ability are significantly positively correlated to each other with a coefficient of 0.37 .

As first specification in Table 7, we reproduce the final specification from Table 4 but eliminate the second insignificant risk measure. The comparison between column (3) in Table 4 and column (1) in Table 7 makes clear that there are no qualitative deviations. The variables "housewife" and "number of savings accounts" lose significance, whereas "upper secondary education" becomes significant. The latter effect might be induced by the changed sample that does not contain any individuals with a university degree.

Then, in column (2) we add the new variable "numeracy (mathscore)" to the baseline specification. This new coefficient has the expected negative sign, indicating that better numeracy is associated to less Allais-type behavior. Second, we add another cognitive ability variable, i.e. the number of animals people can mention within a one-minute interval, to the baseline specification (column 3). This variable is intended to measure the quality of memory and verbal expression. The coefficient is also positive but insignificant.

Third, in column (4) we provide the acid test by putting FSD-violation and numeracy together into the specification. Interestingly, both variables keep their sign and significance, cautiously indicating that FSD-violation does not primarily inform about numeracy but about something else. This other element may be biased processing of probability information (as predicted by PRT).

This picture is reproduced by putting all variables into one specification (5), although numeracy slightly loses its marginal significance. However, more important for our research is 
the fact that coefficients are almost unaffected by the inclusion of additional variables, here the numeracy (mathscore). This is a clear sign that neither FSD violation nor risk taking work here as substitutes for cognitive ability.

Alternative estimation methods. So far, probit estimates of marginal effects were presented as the endogenous variable is a dummy variable (1 if an Allais paradox behavior is observed; 0 if otherwise). The final model, i.e. specification (4) from Table 4 (but excluding the hypothetical investment-item), is shown in Table 8, column (1). In the following, we conduct further robustness tests using alternative methods estimating coefficients and standard errors.

It is possible that the behavior of inhabitants within a village differs from that in other villages because an intensive communication within the village and the village-specific environmental conditions influence behavior. For example, failure of risky investments in one village may increase the risk aversion of other inhabitants within the same village, while people from other villages are not affected by this event because they do not know what happened. In this case, conventional probit estimates are misleading. The effect of individual risk attitude is overestimated or even inconsistent. There are several possibilities to address this problem. Village robust standard errors can be calculated. This solves the Moulton problem (Moulton, 1986) that the variance of a regressor - in our example the variance of the willingness to take risk - is too low if this variable strongly varies between villages but only little within the villages. The results are presented in column (2). Of course, coefficients are the same as in column (1) but the standard errors are also very similar to those from column (1). Some coefficients lose significance due to larger standard errors.

This method does not consider possible correlations between the risk aversion effect on the Allais paradox variable and the village influence. Analogously to time-invariant individual effects in panel models village-invariant household effects can be modeled. This is done in Table 8, column (3). The estimates of the standard errors are larger than in columns (1) and (2) but more similar to specification (2).

Moreover, there may be an interdependent link between the endogenous variable and a regressor. E.g., the math-related variable, measured by the FSD violation, can lead to Allais-type behavior. However, the reverse influence is also possible or a third unobserved influence is responsible that FSD and Allais-type behavior are positively correlated. Under this constellations the FSD effect in Table 8, column (1) is overestimated and inconsistent. An instrumental variable approach solves this problem. It is difficult to find adequate instruments. Lewbel (2012) suggests 
a method that uses only internal information and allows the identification of structural parameters. This is achieved by having regressors that are uncorrelated with the product of heteroscedastic errors. Estimates are shown in Table 8, column (4). A combination between village-robust standard errors and Lewbel is documented in column (5).

Nearly all coefficients have the same sign. In particular, this holds true for all significant variables. Most important for us, the three variables that we have introduced as new explanations of Allais-type behavior consistently keep their sign and significance.

Correlation with "real world" behavior. While this paper is concerned with establishing Allais-type behavior for an under-researched population, and showing relations of this behavior to individual characteristics, it might be tempting to a have a quick preview whether there is any link to real world decision making. As the underlying survey in principle allows for such analyses, we run three correlations between Allais-type behavior and risky decisions.

First, we consider the absolute amount invested in one year for business purposes and find a coefficient of 0.07 ( $p<0.1)$. Second, we look at the number of insurance contracts being held and receive a coefficient of $-0.06(\mathrm{p}<0.05)$. Third, we take the incidence of loan default or late repayment and get a coefficient of $0.28(\mathrm{p}<0.01)$. In addition to these correlations we show in Appendix $\mathrm{C}$ the mean values regarding these three risky behaviors for individuals with and without Allais-type behavior. Overall, the coefficient signs (as well as mean values) do not seem to be surprising as we found above that Allais-type behavior is related to more risk tolerance. While these simple relations would require much more effort on controls, robustness and causality to allow inferences, the relation to loan repayment problems provides indeed a first signal that Allais-type behavior may be related to suboptimal risky behavior.

\section{Conclusions}

This study is the first to examine Allais-type behavior in a larger sample in a poor rural area, i.e. Northeast Thailand. The concern is that inconsistent decision making as demonstrated by Allais-type decisions may be more prevalent in a less developed population and may be an expression of generally sub-optimal decision making. Of course, we cannot compare the overall quality of decision making across countries with our data, but we can safely say that the degree of Allais-type behavior with $54 \%$ of respondents is remarkably high compared to other studies.

Despite this difference to earlier work, we aim for and succeed in replicating the approach by Huck and Müller (2012) who pioneer relating Allais-type behavior to individual socio- 
demographic characteristics in a broad representative sample (of the Netherlands). We confirm three of their four significant relations, all indicating that inconsistent decisions are linked to less ability, such as having less education.

We extend this approach by also considering math-related and risk-related characteristics. Considering three new variables from these domains improves explanatory power (as measured by pseudo $\mathrm{R}^{2}$ ) by about $50 \%$. These three variables all have and keep statistically significant coefficient signs in various specifications. Whereas the math-related characteristic further elaborates on the ability-based explanation of Allais-type behavior, the risk-related characteristics indicate that further influences may play a role. Whatever their interpretation may be, the implication of this relation is unfortunate, because the risk-tolerant and optimistic people tend to make inconsistent decisions under uncertainty (as measured by the Allais experiment). At the same time, we learn that better education, including improved numeracy, tend to reduce inconsistent behavior.

Our theoretical prediction derived from PRT, namely that violations of FSD are related to behavior in the Allais experiment, is supported by our data. This constitutes a challenge for other theories of decision making under risk, e.g. cumulative prospect theory (Tversky and Kahneman, 1992), which cannot explain violations of FSD (for further theoretical and empirical analyses of this issue see Birnbaum (2005) and Birnbaum and Navarette (1998)). In fact, many of these theories assume consistency with FSD explicitly in their axiomatic foundation. Therefore, violations of FSD have to be regarded as random error in these theories. In this case, however, the correlation to behavior in the Allais experiment should not occur. We do not claim that our data provide a stringent test between PRT and alternative theories, here future work under more controlled conditions is needed.

Overall, we contribute to the debate about potential roots of Allais-type behavior by examining a novel kind of population and by uncovering new relations. We are aware that our sample is specific and that it may be favorable to detecting ability-based relations. We hope that the new results stimulate further investigations in order to reveal robust stylized facts across various sample populations and approaches. 


\section{References}

Allais, Maurice (1953), Le comportement de l'homme rationnel devant le risqué: Critique des postulats et axioms de l'école américaine, Econometrica, 21, 503-546.

Allais, Maurice and Ole Hagen (eds.)(1979), Expected utility hypotheses and the Allais paradox: Contemporary discussions of the decisions under uncertainty with Allais' rejoinder, Springer: Berlin.

Andersson, Ola, Jean-Robert Tyran, Erik Wengström and Håkan J. Holm (2016), Risk aversion relates to cognitive ability: Preferences or noise? Journal of the European Economic Association, forthcoming.

Barsky, Robert B., Thomas F. Juster, Miles S. Kimball, and Mathew D. Shapiro (1997), Preference parameters and individual heterogeneity: An experimental approach in the health and retirement study, Quarterly Journal of Economics, 112, 537-579.

Benjamin, Daniel J., Sebastian A. Brown and Jesse M. Shapiro (2013), Who is 'behavioral'? Cognitive ability and anomalous preferences, Journal of the European Economic Association, 11(6), 1231-1255.

Birnbaum, Michael H. (1997), Violations of monotonicity in judgment and decision making, in: A. Marley (Ed.), Choice, decision, and measurement: Essays in honor of R. Duncan Luce, Lawrence Erlbaum Associates.

Birnbaum, Michael H. (1999), Testing critical properties of decision making on the internet, Psychological Science, 10, 399-407.

Birnbaum, Michael H. (2004a), Causes of Allais common consequence paradoxes: An experimental dissection, Journal of Mathematical Psychology, 48, 87-106.

Birnbaum, Michael H. (2004b), Tests of rank-dependent utility and cumulative prospect theory in gambles represented by natural frequencies: Effects of format, event framing, and branch splitting, Organizational Behavior and Human Decision Processes, 95, 40-65.

Birnbaum, Michael H. (2005), A comparison of five models that predict violations of first-order stochastic dominance in risky decision making, Journal of Risk and Uncertainty, 31, 263287.

Birnbaum, Michael H., and Javier Navarrete (1998), Testing descriptive utility theories: Violations of stochastic dominance and cumulative independence, Journal of Risk and Uncertainty, 17, 49-78. 
Burks, Stephen V., Jeffrey P. Carpenter, Lorenz Götte and Aldo Rustichini (2009), Cognitive skills affect economic preferences, strategic behavior, and job attachment, Proceedings of the National Academy of Sciences, 106(19), 7745-7750.

Camerer, Colin F. and Robin M. Hogarth (1999), The effects of financial incentives in experiments: A review and capital-labor-production framework, Journal of Risk and Uncertainty, 19, 7-42.

Charness, Gary and Angelino Viceisza (2015), Comprehension and risk elicitation in the field: Evidence from rural Senegal, Review of Behavioral Economics, forthcoming.

Choi, Syngjoo, Shachar Kariv, Wieland Müller and Dan Silverman (2014), Who is (more) rational? American Economic Review, 104(6), 1518-1550.

Christelis, Dimitris, Tullio Jappelli and Mario Padula (2010), Cognitive abilities and portfolio choice, European Economic Review, 54(1), 18-38.

Cole, Shawn, Thomas Sampson and Bilal Zia (2011), Prices or knowledge? What drives demand for financial services in emerging markets? Journal of Finance, 66(6), 1933-1967.

Conlisk, John (1989), Three variants on the Allais example, American Economic Review, 79, 392-407.

Dohmen, Thomas, Armin Falk, David Huffman and Uwe Sunde (2010), Are risk aversion and impatience related to cognitive ability? American Economic Review, 100, 1238-1260.

Dohmen, Thomas, Armin Falk, David Huffmann, Uwe Sunde, Jürgen Schupp and Gert G. Wagner (2011), Individual risk attitudes: Measurement, determinants and behavioral consequences, Journal of the European Economic Association, 9, 522-550.

Finkelshtain, Israel and Eli Feinerman (1997), Framing the Allais paradox as a daily farm decision problem: tests and explanations, Agricultural Economics, 15, 155-167.

Hardeweg, Bernd, Lukas Menkhoff and Hermann Waibel (2013), Experimentally validated survey evidence on individual risk attitudes in rural Thailand, Economic Development and Cultural Change, 61, 859-888.

Hentschel, Jesko and Peter Lanjouw (1996), Constructing an indicator of consumption for the analysis of poverty: Principles and illustrations with reference to Ecuador, Living standard measurement study working paper no. 124, The World Bank.

Holt, Charles A. and Susan K. Laury (2002), Risk aversion and incentive effects, American Economic Review, 92, 1644-1655. 
Huck, Steffen and Wieland Müller (2012), Allais for all: Revisiting the paradox in a large representative sample, Journal of Risk and Uncertainty, 44, 261-293.

Kahneman, Daniel and Amos Tversky (1979), Prospect theory: An analysis of decision under risk, Econometrica, 47, 263-292.

Klasen, Stephan and Hermann Waibel (Eds.) (2013), Vulnerability to poverty: Theory, measurement and determinants, Palgrave Macmillan.

Levy, Haim (2008), First degree stochastic dominance violations: Decision weights and bounded rationality, Economic Journal, 118, 759-774.

Lewbel, A. (2012), Using heteroscedasticity to identify and estimate mismeasured and endogenous regressor models, Journal of Business and Economics Statistics, 30, 67-80.

Moulton, B. R. (1986), Random group effects and the precision of regression estimates, Journal of Econometrics, 32, 385-397.

Puri, Manju and David T. Robinson (2007), Optimism and economic choice, Journal of Financial Economics, 86, 71-99.

Tanaka, Tomomi, Colin F. Camerer and Quang Nguyen (2010), Risk and time preferences: Linking experimental and household survey data from Vietnam, American Economic Review, 100, 557-571.

Vieider, Ferdinand M., Mathieu Lefebvre, Ranoua Bouchouicha, Thorsten Chmura, Rustamdjan Hakimov, Michal Krawczyk and Peter Martinsson (2015), Common components of risk and uncertainty attitudes across contexts and domains: Evidence from 30 countries, Journal of the European Economic Association, 13, 421-452.

Viscusi, W. Kip (1985), Are individuals Bayesian decision makers? American Economic Review, $75,381-385$.

Viscusi, W. Kip (1989), Prospective reference theory: Toward an explanation of the paradoxes, Journal of Risk and Uncertainty, 2, 235-264.

Viscusi, W. Kip and Charles O’Connor (1984), Adaptive responses to chemical labeling: Are workers Bayesian decision makers? American Economic Review, 74, 942-956.

Viscusi, W. Kip, Wesley A. Magat and Joel Huber (1987), An investigation of the rationality of consumer valuations of multiple health risks, Rand Journal of Economics, 18, 465-479. 
Table 1: Summary statistics of explanatory variables

\begin{tabular}{|c|c|c|c|c|c|c|}
\hline & \multicolumn{2}{|c|}{$\begin{array}{l}\text { Excluded } \\
\text { observations }\end{array}$} & \multicolumn{2}{|c|}{ Restricted sample } & \multicolumn{2}{|c|}{$\begin{array}{l}\text { Tests for equality of } \\
\text { two means }\end{array}$} \\
\hline & Mean & \# Obs. & Mean & \# Obs. & T-stat. & P-values \\
\hline Female & 0.63 & 137 & 0.62 & 778 & 0.56 & 0.57 \\
\hline Age & 52.39 & 135 & 51.88 & 778 & 0.76 & 0.45 \\
\hline Age 17-24 & 0.00 & 135 & 0.01 & 778 & -0.39 & 0.70 \\
\hline Age $25-34$ & 0.06 & 135 & 0.04 & 778 & 1.94 & 0.05 \\
\hline Age $35-44$ & 0.20 & 135 & 0.16 & 778 & 1.59 & 0.11 \\
\hline Age $45-54$ & 0.32 & 135 & 0.40 & 778 & -3.00 & 0.00 \\
\hline Age 55-64 & 0.23 & 135 & 0.28 & 778 & -2.19 & 0.03 \\
\hline Age $\geq 65$ & 0.19 & 135 & 0.10 & 778 & 4.20 & 0.00 \\
\hline Years of education & 5.04 & 111 & 5.57 & 778 & -2.98 & 0.00 \\
\hline No or primary education & 0.89 & 111 & 0.84 & 778 & 2.35 & 0.02 \\
\hline Lower sec. education & 0.06 & 111 & 0.08 & 778 & -1.13 & 0.26 \\
\hline Upper sec. education & 0.03 & 111 & 0.05 & 778 & -1.41 & 0.16 \\
\hline University degree & 0.01 & 111 & 0.03 & 778 & -2.27 & 0.02 \\
\hline Wage-earner & 0.22 & 111 & 0.23 & 778 & -0.29 & 0.77 \\
\hline Self-employed & 0.06 & 111 & 0.05 & 778 & 0.55 & 0.58 \\
\hline Unemployed & 0.02 & 111 & 0.02 & 778 & -0.66 & 0.51 \\
\hline Housewife & 0.03 & 111 & 0.02 & 778 & 1.23 & 0.22 \\
\hline Other occupational status & 0.68 & 111 & 0.67 & 778 & 0.18 & 0.86 \\
\hline Log(income per capita) & 7.20 & 137 & 7.60 & 765 & -8.40 & 0.00 \\
\hline Middle income class & 0.47 & 137 & 0.62 & 778 & -5.17 & 0.00 \\
\hline Log(consump. per capita) & 7.56 & 137 & 7.79 & 774 & -7.04 & 0.00 \\
\hline No. of saving accounts & 0.63 & 134 & 1.76 & 778 & -20.43 & 0.00 \\
\hline FSD violation & 0.68 & 111 & 0.68 & 778 & -0.07 & 0.94 \\
\hline Willingness to take risk & 4.85 & 108 & 5.06 & 778 & -1.28 & 0.20 \\
\hline Hypo. Investments/1000 & 2.23 & 107 & 2.84 & 778 & -7.95 & 0.00 \\
\hline Optimism: better off & 0.48 & 108 & 0.57 & 778 & -2.82 & 0.00 \\
\hline
\end{tabular}

Note: Other occupational status is primarily farmer. The share is 0.58 among the excluded observations and 0.62 in the restricted sample. This means that $92.5 \%$ of the individuals with other occupational status are farmers. 
Table 2: Outcome of the Allais experiment

\begin{tabular}{cccc} 
Allais decisions & Freq. Percent Cum. \\
\hline $\mathrm{AC}$ & &
\end{tabular}

\begin{tabular}{cccc}
\hline AC & 202 & 25.96 & 25.96 \\
AD & 291 & 37.40 & 63.36 \\
BC & 127 & 16.32 & 79.69 \\
BD & 158 & 20.31 & 100.00 \\
\hline Total & 778 & 100.00 &
\end{tabular}

Testing for uniform distribution $(\mathrm{H} 0: \mathrm{P}(\mathrm{AC})=\mathrm{P}(\mathrm{AD})=\mathrm{P}(\mathrm{BC})=\mathrm{P}(\mathrm{BD})=0.25)$ :

$\mathrm{T}=18.64>\mathrm{Chi}^{2}(3 ; 0.95)=7.82$

\begin{tabular}{cccc} 
Allais behavior & Freq. & Percent & Cum. \\
\hline No & 360 & 46.27 & 46.27 \\
Yes & 418 & 53.73 & 100.00 \\
\hline Total & 778 & 100.00 &
\end{tabular}


Table 3: Probit estimates of baseline model and additional explanatory variables

\begin{tabular}{|c|c|c|c|c|}
\hline & (1) & (2) & (3) & (4) \\
\hline Female & $\begin{array}{l}-0.043 \\
(0.040)\end{array}$ & & $\begin{array}{l}-0.025 \\
(0.040)\end{array}$ & \\
\hline Age $25-34$ & $\begin{array}{l}-0.025 \\
(0.259)\end{array}$ & & $\begin{array}{l}-0.058 \\
(0.257)\end{array}$ & \\
\hline Age $35-44$ & $\begin{array}{l}-0.147 \\
(0.242)\end{array}$ & & $\begin{array}{l}-0.164 \\
(0.238)\end{array}$ & \\
\hline Age $45-54$ & $\begin{array}{l}-0.133 \\
(0.241)\end{array}$ & & $\begin{array}{l}-0.144 \\
(0.239)\end{array}$ & \\
\hline Age 55-64 & $\begin{array}{l}-0.262 \\
(0.231)\end{array}$ & & $\begin{array}{l}-0.275 \\
(0.227)\end{array}$ & \\
\hline Age $\geq 65$ & $\begin{array}{l}-0.143 \\
(0.245)\end{array}$ & & $\begin{array}{l}-0.146 \\
(0.243)\end{array}$ & \\
\hline Lower sec. education & $\begin{array}{l}-0.058 \\
(0.072)\end{array}$ & & $\begin{array}{l}-0.070 \\
(0.072)\end{array}$ & \\
\hline Upper sec. education & $\begin{array}{l}-0.127 \\
(0.088)\end{array}$ & & $\begin{array}{l}-0.135 \\
(0.087)\end{array}$ & \\
\hline University degree & $\begin{array}{l}-0.438 * * * \\
(0.080)\end{array}$ & $\begin{array}{l}-0.446 * * * \\
(0.072)\end{array}$ & $\begin{array}{l}-0.447 * * * \\
(0.077)\end{array}$ & $\begin{array}{l}-0.452 * * * \\
(0.071)\end{array}$ \\
\hline Wage-earner & $\begin{array}{l}-0.055 \\
(0.059)\end{array}$ & & $\begin{array}{l}-0.057 \\
(0.060)\end{array}$ & \\
\hline Self-employed & $\begin{array}{l}-0.019 \\
(0.083)\end{array}$ & & $\begin{array}{l}-0.036 \\
(0.083)\end{array}$ & \\
\hline Unemployed & $\begin{array}{l}0.411 * * * \\
(0.064)\end{array}$ & $\begin{array}{l}0.415 * * * \\
(0.060)\end{array}$ & $\begin{array}{l}0.411 * * * \\
(0.064)\end{array}$ & $\begin{array}{l}0.417 * * * \\
(0.059)\end{array}$ \\
\hline Housewife & $\begin{array}{l}0.316 * * * \\
(0.105)\end{array}$ & $\begin{array}{l}0.323 * * * \\
(0.102)\end{array}$ & $\begin{array}{l}0.319 * * * \\
(0.103)\end{array}$ & $\begin{array}{l}0.327 * * * \\
(0.099)\end{array}$ \\
\hline Middle income class & $\begin{array}{l}0.020 \\
(0.039)\end{array}$ & & $\begin{array}{l}0.024 \\
(0.039)\end{array}$ & \\
\hline No. of sav. accounts & $\begin{array}{l}-0.038^{*} \\
(0.021)\end{array}$ & $\begin{array}{l}-0.046 * * \\
(0.019)\end{array}$ & $\begin{array}{l}-0.040 * \\
(0.021)\end{array}$ & $\begin{array}{l}-0.049 * * \\
(0.020)\end{array}$ \\
\hline FSD violation & & & $\begin{array}{l}0.141 * * * \\
(0.040)\end{array}$ & $\begin{array}{l}0.134 * * * \\
(0.039)\end{array}$ \\
\hline Observations & 778 & 778 & 778 & 778 \\
\hline Pseudo R2 & 0.06 & 0.04 & 0.07 & 0.06 \\
\hline Prob > chi2 & 0.000 & 0.000 & 0.000 & 0.000 \\
\hline
\end{tabular}

Notes: Marginal effects are reported. Standard errors in parentheses. * $\mathrm{p}<0.1, * * \mathrm{p}<0.05, * * * \mathrm{p}$ $<0.01$. (1) baseline model (BM); (2) only significant regressors from (1); (3) BM+FSD violation; (4) only significant regressors from (3). 
Table 4: Probit estimates of baseline model and additional explanatory variables

\begin{tabular}{|c|c|c|c|c|}
\hline & (1) & (2) & (3) & (4) \\
\hline \multirow[t]{2}{*}{ Female } & -0.043 & -0.030 & -0.059 & -0.036 \\
\hline & $(0.040)$ & $(0.040)$ & $(0.040)$ & $(0.042)$ \\
\hline \multirow[t]{2}{*}{ Age $25-34$} & 0.015 & 0.009 & 0.047 & 0.065 \\
\hline & $(0.261)$ & $(0.261)$ & $(0.251)$ & $(0.251)$ \\
\hline \multirow[t]{2}{*}{ Age $35-44$} & -0.104 & -0.118 & -0.084 & -0.048 \\
\hline & $(0.250)$ & $(0.248)$ & $(0.244)$ & $(0.247)$ \\
\hline \multirow[t]{2}{*}{ Age $45-54$} & -0.080 & -0.100 & -0.059 & -0.005 \\
\hline & $(0.248)$ & $(0.246)$ & $(0.241)$ & $(0.245)$ \\
\hline \multirow[t]{2}{*}{ Age 55-64 } & -0.210 & -0.231 & -0.190 & -0.138 \\
\hline & $(0.242)$ & $(0.238)$ & $(0.237)$ & $(0.244)$ \\
\hline \multirow[t]{2}{*}{ Age $\geq 65$} & -0.084 & -0.101 & -0.055 & 0.022 \\
\hline & $(0.255)$ & $(0.253)$ & $(0.249)$ & $(0.251)$ \\
\hline \multirow[t]{2}{*}{ Lower sec. education } & -0.053 & -0.048 & -0.092 & -0.098 \\
\hline & $(0.072)$ & $(0.073)$ & $(0.073)$ & $(0.073)$ \\
\hline \multirow[t]{2}{*}{ Upper sec. education } & -0.131 & -0.127 & -0.122 & -0.131 \\
\hline & $(0.088)$ & $(0.087)$ & $(0.088)$ & $(0.088)$ \\
\hline \multirow[t]{2}{*}{ University degree } & $-0.450 * * *$ & $-0.448 * * *$ & $-0.442 * * *$ & $-0.464 * * *$ \\
\hline & $(0.075)$ & $(0.076)$ & $(0.079)$ & $(0.070)$ \\
\hline \multirow[t]{2}{*}{ Wage-earner } & -0.059 & -0.052 & -0.079 & -0.084 \\
\hline & $(0.059)$ & $(0.059)$ & $(0.060)$ & $(0.061)$ \\
\hline \multirow[t]{2}{*}{ Self-employed } & -0.040 & -0.025 & 0.001 & -0.038 \\
\hline & $(0.083)$ & $(0.083)$ & $(0.083)$ & $(0.084)$ \\
\hline \multirow[t]{2}{*}{ Unemployed } & $0.410 * * *$ & $0.409 * * *$ & $0.428 * * *$ & $0.424 * * *$ \\
\hline & $(0.067)$ & $(0.067)$ & $(0.052)$ & $(0.055)$ \\
\hline \multirow[t]{2}{*}{ Housewife } & $0.308 * * *$ & $0.316 * * *$ & $0.285 * *$ & $0.276^{* *}$ \\
\hline & $(0.109)$ & $(0.105)$ & $(0.117)$ & $(0.120)$ \\
\hline \multirow[t]{2}{*}{ Middle income class } & 0.016 & 0.022 & 0.005 & 0.004 \\
\hline & $(0.039)$ & $(0.039)$ & $(0.039)$ & $(0.040)$ \\
\hline \multirow[t]{2}{*}{ No. of saving accounts } & $-0.034 *$ & $-0.042 * *$ & $-0.042 * *$ & $-0.042 * *$ \\
\hline & $(0.021)$ & $(0.021)$ & $(0.021)$ & $(0.021)$ \\
\hline \multirow[t]{2}{*}{ Willingness to take risk } & $0.019 * *$ & & & $0.019 *$ \\
\hline & $(0.008)$ & & & $(0.010)$ \\
\hline \multirow[t]{2}{*}{ Hypo. investments/1000 } & & $0.032 *$ & & 0.011 \\
\hline & & $(0.017)$ & & $(0.021)$ \\
\hline \multirow[t]{2}{*}{ Optimism: better off } & & & $0.155 * * *$ & $0.160 * * *$ \\
\hline & & & $(0.039)$ & $(0.039)$ \\
\hline \multirow[t]{2}{*}{ FSD violation } & & & & $0.145 * * *$ \\
\hline & & & & $(0.040)$ \\
\hline Observations & 778 & 778 & 778 & 778 \\
\hline Pseudo R2 & 0.06 & 0.06 & 0.07 & 0.09 \\
\hline Prob > chi 2 & 0.000 & 0.000 & 0.000 & 0.000 \\
\hline
\end{tabular}


Table 5: Probit estimates with alternatively measured variables

\begin{tabular}{|c|c|c|c|c|}
\hline & (1) & (2) & (3) & (4) \\
\hline Female & $\begin{array}{l}-0.045 \\
(0.039)\end{array}$ & $\begin{array}{l}-0.045 \\
(0.039)\end{array}$ & $\begin{array}{l}-0.044 \\
(0.039)\end{array}$ & $\begin{array}{l}-0.040 \\
(0.039)\end{array}$ \\
\hline Age & $\begin{array}{l}-0.004 * * \\
(0.002)\end{array}$ & $\begin{array}{l}-0.005^{* * * *} \\
(0.002)\end{array}$ & $\begin{array}{l}-0.005 * * * \\
(0.002)\end{array}$ & $\begin{array}{l}-0.004 * * \\
(0.002)\end{array}$ \\
\hline Years of education & $\begin{array}{l}-0.020 * * * \\
(0.007)\end{array}$ & $\begin{array}{l}-0.022 * * * \\
(0.007)\end{array}$ & $\begin{array}{l}-0.022 * * * \\
(0.007)\end{array}$ & $\begin{array}{l}-0.020 * * * \\
(0.007)\end{array}$ \\
\hline Wage-earner & $\begin{array}{l}-0.074 \\
(0.056)\end{array}$ & $\begin{array}{l}-0.076 \\
(0.056)\end{array}$ & $\begin{array}{l}-0.076 \\
(0.056)\end{array}$ & $\begin{array}{l}-0.081 \\
(0.056)\end{array}$ \\
\hline Self-employed & $\begin{array}{l}-0.022 \\
(0.082)\end{array}$ & $\begin{array}{l}-0.041 \\
(0.083)\end{array}$ & $\begin{array}{l}-0.040 \\
(0.085)\end{array}$ & $\begin{array}{l}0.018 \\
(0.084)\end{array}$ \\
\hline Unemployed & $\begin{array}{l}0.411 * * * \\
(0.062)\end{array}$ & $\begin{array}{l}0.413 * * * \\
(0.062)\end{array}$ & $\begin{array}{l}0.413 * * * \\
(0.061)\end{array}$ & $\begin{array}{l}0.415 * * * \\
(0.059)\end{array}$ \\
\hline Housewife & $\begin{array}{l}0.327 * * * \\
(0.101)\end{array}$ & $\begin{array}{l}0.331 * * * \\
(0.100)\end{array}$ & $\begin{array}{l}0.323 * * * \\
(0.102)\end{array}$ & $\begin{array}{l}0.323 * * * \\
(0.101)\end{array}$ \\
\hline Middle income class & $\begin{array}{l}0.029 \\
(0.038)\end{array}$ & & & \\
\hline No. of saving accounts & $\begin{array}{l}-0.039 * \\
(0.020)\end{array}$ & $\begin{array}{l}-0.043 * * \\
(0.021)\end{array}$ & $\begin{array}{l}-0.040 * \\
(0.020)\end{array}$ & $\begin{array}{l}-0.044 * * \\
(0.021)\end{array}$ \\
\hline $\log ($ income $)$ & & $\begin{array}{l}0.037 \\
(0.023)\end{array}$ & & \\
\hline Log(income per capita) & & & $\begin{array}{l}0.045 * \\
(0.025)\end{array}$ & \\
\hline Log(consump. per capita) & & & & $\begin{array}{l}0.029 \\
(0.035)\end{array}$ \\
\hline Observations & 778 & 768 & 765 & 774 \\
\hline Pseudo R2 & 0.04 & 0.05 & 0.04 & 0.04 \\
\hline Prob $>$ chi 2 & 0.000 & 0.000 & 0.000 & 0.000 \\
\hline
\end{tabular}


Table 6: Probit estimates of baseline model with additional explanatory variables

\begin{tabular}{|c|c|c|c|}
\hline & $\begin{array}{c}\mathrm{AD}+\mathrm{BC} \\
\text { (1) }\end{array}$ & $\begin{array}{l}\mathrm{AD} \\
(2)\end{array}$ & $\begin{array}{l}\mathrm{BC} \\
(3)\end{array}$ \\
\hline Female & $\begin{array}{l}-0.036 \\
(0.042)\end{array}$ & $\begin{array}{l}-0.053 \\
(0.040)\end{array}$ & $\begin{array}{c}0.011 \\
(0.028)\end{array}$ \\
\hline Age $25-34$ & $\begin{array}{c}0.065 \\
(0.251)\end{array}$ & $\begin{array}{l}-0.182 \\
(0.191)\end{array}$ & $\begin{array}{l}0.896^{* * * *} \\
(0.010)\end{array}$ \\
\hline Age $35-44$ & $\begin{array}{l}-0.048 \\
(0.247)\end{array}$ & $\begin{array}{c}-0.312^{* * *} \\
(0.152)\end{array}$ & $\begin{array}{l}0.975^{* * * *} \\
(0.004)\end{array}$ \\
\hline Age $45-54$ & $\begin{array}{l}-0.005 \\
(0.245)\end{array}$ & $\begin{array}{l}-0.326 \\
(0.214)\end{array}$ & $\begin{array}{l}0.992^{* * * *} \\
(0.004)\end{array}$ \\
\hline Age 55-64 & $\begin{array}{l}-0.138 \\
(0.244)\end{array}$ & $\begin{array}{c}-0.413^{* * * *} \\
(0.158)\end{array}$ & $\begin{array}{c}0.996^{* * * *} \\
(0.001)\end{array}$ \\
\hline Age $>=65$ & $\begin{array}{c}0.022 \\
(0.251)\end{array}$ & $\begin{array}{c}-0.307^{* *} \\
(0.133)\end{array}$ & $\begin{array}{c}0.953^{* * * *} \\
(0.006)\end{array}$ \\
\hline Lower sec. education & $\begin{array}{l}-0.098 \\
(0.073)\end{array}$ & $\begin{array}{l}-0.045 \\
(0.068)\end{array}$ & $\begin{array}{l}-0.051 \\
(0.045)\end{array}$ \\
\hline Upper sec. education & $\begin{array}{l}-0.131 \\
(0.088)\end{array}$ & $\begin{array}{c}-0.192^{* * * *} \\
(0.067)\end{array}$ & $\begin{array}{c}0.074 \\
(0.079)\end{array}$ \\
\hline University degree & $\begin{array}{c}-0.464^{* * *} \\
(0.070)\end{array}$ & $\begin{array}{c}-0.310^{* * * *} \\
(0.056)\end{array}$ & \\
\hline Wage-earner & $\begin{array}{l}-0.084 \\
(0.061)\end{array}$ & $\begin{array}{l}-0.002 \\
(0.058)\end{array}$ & $\begin{array}{c}-0.074^{* *} \\
(0.034)\end{array}$ \\
\hline Self-employed & $\begin{array}{l}-0.038 \\
(0.084)\end{array}$ & $\begin{array}{l}-0.024 \\
(0.080)\end{array}$ & $\begin{array}{l}-0.011 \\
(0.058)\end{array}$ \\
\hline Unemployed & $\begin{array}{c}0.424^{\text {**** }} \\
(0.055)\end{array}$ & $\begin{array}{l}0.217^{*} \\
(0.120)\end{array}$ & $\begin{array}{l}0.238^{* * *} \\
(0.120)\end{array}$ \\
\hline Housewife & $\begin{array}{l}0.276^{* *} \\
(0.120)\end{array}$ & $\begin{array}{c}0.214 \\
(0.144)\end{array}$ & $\begin{array}{c}0.042 \\
(0.113)\end{array}$ \\
\hline Middle income class & $\begin{array}{c}0.004 \\
(0.040)\end{array}$ & $\begin{array}{l}-0.021 \\
(0.038)\end{array}$ & $\begin{array}{c}0.020 \\
(0.027)\end{array}$ \\
\hline No. of saving accounts & $\begin{array}{c}-0.042^{* *} \\
(0.021)\end{array}$ & $\begin{array}{l}-0.017 \\
(0.020)\end{array}$ & $\begin{array}{l}-0.022 \\
(0.016)\end{array}$ \\
\hline FSD violation & $\begin{array}{c}0.145^{\text {**** }} \\
(0.040)\end{array}$ & $\begin{array}{c}0.176^{* * * *} \\
(0.036)\end{array}$ & $\begin{array}{l}-0.028 \\
(0.029)\end{array}$ \\
\hline Willingness to take risk & $\begin{array}{l}0.019^{*} \\
(0.010)\end{array}$ & $\begin{array}{c}0.002 \\
(0.010)\end{array}$ & $\begin{array}{l}0.016^{* *} \\
(0.007)\end{array}$ \\
\hline Hypo.invest/1000 & $\begin{array}{c}0.011 \\
(0.021)\end{array}$ & $\begin{array}{c}0.024 \\
(0.020)\end{array}$ & $\begin{array}{l}-0.017 \\
(0.015)\end{array}$ \\
\hline Optimism: better off & $\begin{array}{c}0.160^{\text {**** }} \\
(0.039)\end{array}$ & $\begin{array}{l}0.094^{* * *} \\
(0.037)\end{array}$ & $\begin{array}{l}0.062^{* * *} \\
(0.027)\end{array}$ \\
\hline Observations & 778 & 778 & 778 \\
\hline Pseudo $R^{2}$ & 0.09 & 0.07 & 0.05 \\
\hline Prob > chi2 & 0.000 & 0.000 & 0.030 \\
\hline
\end{tabular}

Notes: Marginal effects are reported. Standard errors in parentheses. $* \mathrm{p}<0.1, * * \mathrm{p}<0.05, * * * \mathrm{p}<0.01$. 
Table 7: Specification with mathscore and memory measure at a restricted sample

\begin{tabular}{|c|c|c|c|c|c|}
\hline & $(1)$ & $(2)$ & (3) & $(4)$ & $(5)$ \\
\hline \multirow[t]{2}{*}{ Female } & -0.052 & -0.042 & -0.033 & -0.032 & -0.059 \\
\hline & $(0.051)$ & $(0.049)$ & $(0.050)$ & $(0.050)$ & $(0.051)$ \\
\hline \multirow[t]{2}{*}{ Age $25-34$} & $0.335 * *$ & 0.288 & 0.301 & 0.257 & $0.329 * *$ \\
\hline & $(0.143)$ & $(0.193)$ & $(0.183)$ & $(0.222)$ & $(0.150)$ \\
\hline \multirow[t]{2}{*}{ Age $35-44$} & -0.012 & -0.072 & -0.046 & -0.116 & -0.035 \\
\hline & $(0.306)$ & $(0.318)$ & $(0.316)$ & $(0.315)$ & $(0.311)$ \\
\hline \multirow[t]{2}{*}{ Age 45-54 } & 0.047 & -0.054 & -0.019 & -0.089 & 0.014 \\
\hline & $(0.300)$ & $(0.310)$ & $(0.309)$ & $(0.306)$ & $(0.304)$ \\
\hline \multirow[t]{2}{*}{ Age 55-64 } & -0.022 & -0.143 & -0.105 & -0.179 & -0.057 \\
\hline & $(0.305)$ & $(0.312)$ & $(0.313)$ & $(0.307)$ & $(0.309)$ \\
\hline \multirow[t]{2}{*}{ Age $\geq 65$} & 0.030 & -0.129 & -0.087 & -0.153 & -0.005 \\
\hline & $(0.306)$ & $(0.324)$ & $(0.325)$ & $(0.318)$ & $(0.314)$ \\
\hline \multirow[t]{2}{*}{ Lower sec. education } & $-0.163^{*}$ & -0.078 & -0.106 & -0.078 & -0.142 \\
\hline & $(0.091)$ & $(0.089)$ & $(0.090)$ & $(0.090)$ & $(0.092)$ \\
\hline \multirow[t]{2}{*}{ Upper sec. education } & $-0.375 * * *$ & $-0.321 * * *$ & $-0.363 * * *$ & $-0.338 * * *$ & $-0.345 * * *$ \\
\hline & $(0.099)$ & $(0.109)$ & $(0.102)$ & $(0.106)$ & $(0.106)$ \\
\hline \multirow[t]{2}{*}{ Wage-earner } & $-0.129 *$ & -0.125 & $-0.131 *$ & -0.119 & -0.124 \\
\hline & $(0.078)$ & $(0.076)$ & $(0.076)$ & $(0.077)$ & $(0.078)$ \\
\hline \multirow[t]{2}{*}{ Self-employed } & 0.037 & 0.033 & 0.032 & 0.001 & 0.038 \\
\hline & $(0.114)$ & $(0.111)$ & $(0.111)$ & $(0.114)$ & $(0.114)$ \\
\hline \multirow[t]{2}{*}{ Unemployed } & $0.391 * * *$ & $0.377 * * *$ & $0.382 * * *$ & $0.379 * * *$ & $0.388 * * *$ \\
\hline & $(0.054)$ & $(0.068)$ & $(0.063)$ & $(0.066)$ & $(0.056)$ \\
\hline \multirow[t]{2}{*}{ House wife } & 0.156 & 0.203 & 0.212 & 0.200 & 0.148 \\
\hline & $(0.147)$ & $(0.135)$ & $(0.132)$ & $(0.134)$ & $(0.149)$ \\
\hline \multirow[t]{2}{*}{ Middle income class } & $0.105 * *$ & $0.126 * * *$ & $0.126 * * *$ & $0.124 * *$ & $0.105 * *$ \\
\hline & $(0.050)$ & $(0.049)$ & $(0.049)$ & $(0.049)$ & $(0.050)$ \\
\hline \multirow[t]{2}{*}{ No. of sav. accounts } & 0.021 & 0.017 & 0.018 & 0.016 & 0.018 \\
\hline & $(0.027)$ & $(0.026)$ & $(0.026)$ & $(0.027)$ & $(0.027)$ \\
\hline \multirow[t]{2}{*}{ Optimism: better off } & $0.191 * * *$ & & & & $0.188 * * *$ \\
\hline & $(0.051)$ & & & & $(0.051)$ \\
\hline \multirow[t]{2}{*}{ FSD violation } & $0.112 * *$ & & & $0.100 *$ & $0.120 * *$ \\
\hline & $(0.054)$ & & & $(0.053)$ & $(0.054)$ \\
\hline \multirow[t]{2}{*}{ Willing to take risk } & $0.021 *$ & & & & $0.019^{*}$ \\
\hline & $(0.011)$ & & & & $(0.011)$ \\
\hline \multicolumn{2}{|l|}{ Mathscore } & $-0.036 *$ & & $-0.040 *$ & -0.034 \\
\hline (numeracy) & & $(0.021)$ & & $(0.022)$ & $(0.022)$ \\
\hline \multicolumn{2}{|l|}{$\begin{array}{l}\text { No. of animals } \\
\text { (memory measure) }\end{array}$} & & $\begin{array}{l}0.001 \\
(0.005)\end{array}$ & & \\
\hline Observations & 476 & 476 & 476 & 476 & 476 \\
\hline Pseudo R2 & 0.08 & 0.06 & 0.06 & 0.06 & 0.09 \\
\hline Prob > chi2 & 0.000 & 0.001 & 0.002 & 0.000 & 0.000 \\
\hline
\end{tabular}


Table 8: Alternative estimation methods of baseline model (and extensions)

\begin{tabular}{|c|c|c|c|c|c|}
\hline & Probit & $\begin{array}{c}\text { Probit } \\
\text { with village } \\
\text { robust std. } \\
\text { errors } \\
\text { (2) }\end{array}$ & $\begin{array}{c}\text { Probit } \\
\text { with village- } \\
\text { invariant } \\
\text { effects } \\
\text { (3) }\end{array}$ & Lewbel & $\begin{array}{l}\text { Lewbel } \\
\text { with village } \\
\text { robust std. } \\
\text { errors } \\
(5)\end{array}$ \\
\hline Female & $\begin{array}{l}-0.040 \\
(0.041)\end{array}$ & $\begin{array}{l}-0.040 \\
(0.062)\end{array}$ & $\begin{array}{l}-0.088 \\
(0.130)\end{array}$ & $\begin{array}{l}-0.043 \\
(0.037)\end{array}$ & $\begin{array}{l}-0.043 \\
(0.057)\end{array}$ \\
\hline Age $25-34$ & $\begin{array}{l}0.061 \\
(0.251)\end{array}$ & $\begin{array}{l}0.061 \\
(0.368)\end{array}$ & $\begin{array}{l}0.756 \\
(0.792)\end{array}$ & $\begin{array}{l}-0.007 \\
(0.230)\end{array}$ & $\begin{array}{l}-0.007 \\
(0.306)\end{array}$ \\
\hline Age $35-44$ & $\begin{array}{l}-0.050 \\
(0.247)\end{array}$ & $\begin{array}{l}-0.050 \\
(0.350)\end{array}$ & $\begin{array}{l}0.298 \\
(0.749)\end{array}$ & $\begin{array}{l}-0.117 \\
(0.219)\end{array}$ & $\begin{array}{l}-0.117 \\
(0.277)\end{array}$ \\
\hline Age $45-54$ & $\begin{array}{l}-0.007 \\
(0.244)\end{array}$ & $\begin{array}{l}-0.007 \\
(0.335)\end{array}$ & $\begin{array}{l}0.579 \\
(0.752)\end{array}$ & $\begin{array}{l}-0.075 \\
(0.217)\end{array}$ & $\begin{array}{l}-0.075 \\
(0.263)\end{array}$ \\
\hline Age 55-64 & $\begin{array}{l}-0.140 \\
(0.243)\end{array}$ & $\begin{array}{l}-0.140 \\
(0.333)\end{array}$ & $\begin{array}{l}0.101 \\
(0.755)\end{array}$ & $\begin{array}{l}-0.196 \\
(0.218)\end{array}$ & $\begin{array}{l}-0.196 \\
(0.265)\end{array}$ \\
\hline Age $\geq 65$ & $\begin{array}{l}0.017 \\
(0.250)\end{array}$ & $\begin{array}{l}0.017 \\
(0.352)\end{array}$ & $\begin{array}{l}0.610 \\
(0.780)\end{array}$ & $\begin{array}{l}-0.052 \\
(0.223)\end{array}$ & $\begin{array}{l}-0.052 \\
(0.283)\end{array}$ \\
\hline Lower sec. education & $\begin{array}{l}-0.102 \\
(0.073)\end{array}$ & $\begin{array}{l}-0.102 \\
(0.109)\end{array}$ & $\begin{array}{l}-0.304 \\
(0.222)\end{array}$ & $\begin{array}{l}-0.095 \\
(0.067)\end{array}$ & $\begin{array}{l}-0.095 \\
(0.100)\end{array}$ \\
\hline Upper sec. education & $\begin{array}{l}-0.133 \\
(0.088)\end{array}$ & $\begin{array}{l}-0.133 \\
(0.138)\end{array}$ & $\begin{array}{l}-0.368 \\
(0.276)\end{array}$ & $\begin{array}{l}-0.120 \\
(0.083)\end{array}$ & $\begin{array}{l}-0.120 \\
(0.132)\end{array}$ \\
\hline University degree & $\begin{array}{l}-0.464 * * * \\
(0.070)\end{array}$ & $\begin{array}{l}-0.464 * * * \\
(0.072)\end{array}$ & $\begin{array}{l}-1.651 * * * \\
(0.506)\end{array}$ & $\begin{array}{l}-0.411 * * * \\
(0.109)\end{array}$ & $\begin{array}{l}-0.411 * * * \\
(0.097)\end{array}$ \\
\hline Wage-earner & $\begin{array}{l}-0.086 \\
(0.060)\end{array}$ & $\begin{array}{l}-0.086 \\
(0.091)\end{array}$ & $\begin{array}{l}-0.250 \\
(0.204)\end{array}$ & $\begin{array}{l}-0.079 \\
(0.055)\end{array}$ & $\begin{array}{l}-0.079 \\
(0.083)\end{array}$ \\
\hline Self-employed & $\begin{array}{l}-0.039 \\
(0.084)\end{array}$ & $\begin{array}{l}-0.039 \\
(0.108)\end{array}$ & $\begin{array}{l}-0.024 \\
(0.260)\end{array}$ & $\begin{array}{l}-0.037 \\
(0.078)\end{array}$ & $\begin{array}{l}-0.037 \\
(0.103)\end{array}$ \\
\hline Unemployed & $\begin{array}{l}0.425 * * * \\
(0.055)\end{array}$ & $\begin{array}{l}0.425 * * * \\
(0.055)\end{array}$ & $\begin{array}{l}1.503 * * \\
(0.637)\end{array}$ & $\begin{array}{l}0.431 * * * \\
(0.112)\end{array}$ & $\begin{array}{l}0.431 * * * \\
(0.074)\end{array}$ \\
\hline Housewife & $\begin{array}{l}0.275^{* *} \\
(0.121)\end{array}$ & $\begin{array}{l}0.275 \\
(0.180)\end{array}$ & $\begin{array}{l}0.683 \\
(0.514)\end{array}$ & $\begin{array}{l}0.262 * \\
(0.139)\end{array}$ & $\begin{array}{l}0.262 \\
(0.169)\end{array}$ \\
\hline Middle income class & $\begin{array}{l}0.003 \\
(0.039)\end{array}$ & $\begin{array}{l}0.003 \\
(0.063)\end{array}$ & $\begin{array}{l}-0.012 \\
(0.126)\end{array}$ & $\begin{array}{l}-0.002 \\
(0.036)\end{array}$ & $\begin{array}{l}-0.002 \\
(0.057)\end{array}$ \\
\hline No. of sav. accounts & $\begin{array}{l}-0.040^{*} \\
(0.021)\end{array}$ & $\begin{array}{l}-0.040 \\
(0.032)\end{array}$ & $\begin{array}{l}-0.179 * * * \\
(0.068)\end{array}$ & $\begin{array}{l}-0.036^{*} \\
(0.019)\end{array}$ & $\begin{array}{l}-0.036 \\
(0.030)\end{array}$ \\
\hline Willing to take risk & $\begin{array}{l}0.022 * * * \\
(0.008)\end{array}$ & $\begin{array}{l}0.022 * \\
(0.011)\end{array}$ & $\begin{array}{l}0.071 * * * \\
(0.027)\end{array}$ & $\begin{array}{l}0.019 * * \\
(0.008)\end{array}$ & $\begin{array}{l}0.019 * \\
(0.010)\end{array}$ \\
\hline Optimism: better off & $\begin{array}{l}0.160 * * * \\
(0.039)\end{array}$ & $\begin{array}{l}0.160 * * * \\
(0.058)\end{array}$ & $\begin{array}{l}0.472 * * * \\
(0.123)\end{array}$ & $\begin{array}{l}0.150 * * * \\
(0.036)\end{array}$ & $\begin{array}{r}.150 * * * \\
(0.054)\end{array}$ \\
\hline FSD violation & $\begin{array}{l}0.146 * * * \\
(0.040)\end{array}$ & $\begin{array}{l}0.146 * * \\
(0.065)\end{array}$ & $\begin{array}{l}0.409 * * * \\
(0.128)\end{array}$ & $\begin{array}{l}0.135 * * * \\
(0.037)\end{array}$ & $\begin{array}{l}0.135 * * \\
(0.060)\end{array}$ \\
\hline Observations & 778 & 778 & 778 & 778 & 778 \\
\hline Pseudo (centered) $\mathrm{R}^{2}$ & 0.09 & 0.09 & - & $(0.11)$ & $(0.11)$ \\
\hline Prob $>\mathrm{Chi}^{2}(\mathrm{~F})$ & 0.000 & 0.000 & 0.000 & $(0.000)$ & $(0.000)$ \\
\hline
\end{tabular}

Notes: Marginal effects; standard errors in parentheses. $* p<0.1, * * p<0.05$, *** $p<0.01$. 


\section{Appendix A. Description of the experiments}

The decision tasks were conducted as described in the following instructions. Each enumerator had a set of six bags, each representing one of the four alternatives of the Allais questions and the two alternatives to elicit FSD violations. Each bag contained 100 cards displaying the respective payoffs, with the number of cards of each payoff corresponding to the respective probability.

\section{Game}

This is a game to learn about your behavior towards choices. It is just for research purposes. You will be asked to make a few decisions. These decisions lead to outcomes where you may win money depending on your choice; however, you can never lose any money.

In the following we ask you to draw a card from one out of two bags. In each bag there are 100 cards. The 100 cards represent different pay-offs, written on each card. This pay-off varies between 0 and 100 Baht:

General procedure

(1) At the beginning we tell how many cards with which pay-offs are in the bags.

(2) Then, please, choose which bag you prefer.

(3) Finally, you draw one card (without seeing it) from the chosen bag and you will receive the amount in Baht for which this card stands.

Do you want to participate in the game?

7 Participate in game $\quad$ Yes: $\square$ No: $\square$

If no, what is the reason why you do not want to participate in the game?

8 Reason of no-participation Religion:

Bad Experience:

Never play:

Other, specify:

Procedure for choice 1 and 2:

We ask you to make two choices (choice 1 and choice 2) between two bags each with different combinations of cards. Then the enumerator will flip a coin. If the result is "king", you can draw a card from the bag of your choice 1. If the result is "palace" then you can draw a card from the bag of your choice 2 . From which bag would you prefer to draw a card, considering that you will receive the pay-off written on the card you draw?

Choice 1:

Bag A

100 cards to win Bt 75
Bag B

80 cards to win Bt 100

20 cards to win Bt 0 
What is your choice 1 ?

9 Choice 1

A: $\square$ B:

Choice 2:

Bag C

Bag D

25 cards to win Bt 75

20 cards to win Bt 100

75 cards to win Bt 0

80 cards to win Bt 0

What is your choice 2?
10 Choice 2
C:
D:

What is the result of the coin toss?

11 Coin

King:

Palace:

PAY-OFF

What was the pay-off written on the card drawn?

12

Pay-off 1

0:

75:

100:

Procedure for choice 3:

Now you can win additional money by making one more choice (choice 3 ). From which bag do you prefer to draw a card?

Choice 3:

Bag E

90 cards to win $\mathrm{Bt} 96$

5 cards to win Bt 14

5 cards to win Bt 12
Bag F

85 cards to win Bt 96

5 cards to win Bt 90

10 cards to win Bt 12

What is your choice 3 ?
13 Choice 3
E:
F:

PAY-OFF

What was the pay-off written on the card drawn?
14
Pay-off 2
12:
14:
90:
96:

Total amount received THB.

Signature

Name (in block letters) 


\section{Appendix B. Description of the tasks on cognitive ability}

The first task is a measure of memory and verbal ability. The numeracy variable is based on answers to the following six questions which are displayed below (question 2 to question7), and the respective "mathscore" is constructed as number of correct answers (ranging from 0 to 6 ).

1 I would like you to name as many different animals as you can in 60 seconds. Enumerator: write responses in box below. Please, do not tell the respondent the whether the answer is right or wrong. Please mark answers using check list |.)

\begin{tabular}{|c|c|c|c|}
\hline 2 & What is $45+72$ & $\begin{array}{l}\text { Please fill in answer here or } \\
\quad \text { tick box to the right! }\end{array}$ & \begin{tabular}{|l}
$\square$ Do not know \\
No answer
\end{tabular} \\
\hline 3 & $\begin{array}{l}\text { If you have four friends and would like to give each of } \\
\text { your friends four sweets, how many sweets do you need? }\end{array}$ & & $\begin{array}{l}\square \text { Do not know } \\
\text { No answer }\end{array}$ \\
\hline 4 & What is $5 \%$ of $200 ?$ & & $\begin{array}{l}\square \text { Do not know } \\
\text { No answer }\end{array}$ \\
\hline 5 & $\begin{array}{l}\text { Suppose you want to buy a bag of rice that costs } 270 \\
\text { Baht. You only have one } 1000 \text { Baht note. How much } \\
\text { change will you get? }\end{array}$ & & \begin{tabular}{|l}
$\square$ Do not know \\
No answer
\end{tabular} \\
\hline 6 & $\begin{array}{l}\text { In a sale, a shop is selling all items at half price. Before } \\
\text { the sale a mattress costs } 3000 \text { Baht. How much will the } \\
\text { mattress cost in the sale? }\end{array}$ & \begin{tabular}{|l}
1500 Baht \\
-4500 Baht \\
-6000 Baht
\end{tabular} & \begin{tabular}{|l}
$\square$ Do not know \\
No answer
\end{tabular} \\
\hline 7 & $\begin{array}{l}\text { A second-hand motorbike dealer is selling a motorbike } \\
\text { for } 12000 \text { Baht. This is two thirds of what it costs new. } \\
\text { How much did the motorbike cost new? }\end{array}$ & $\begin{array}{r}9000 \text { Baht } \\
-16000 \text { Baht } \\
-18000 \text { Baht } \\
24000 \text { Baht }\end{array}$ & $\begin{array}{l}\square \text { Do not know } \\
\text { No answer }\end{array}$ \\
\hline
\end{tabular}




\section{Appendix C. Risky decisions of individuals with and without Allais-type behavior}

Histogram of the mean of investments, mean of the number of insurances and the ratio of loan defaults or late repayments, split by individuals with $(=1)$ and without $(=0)$ Allais-type behavior.
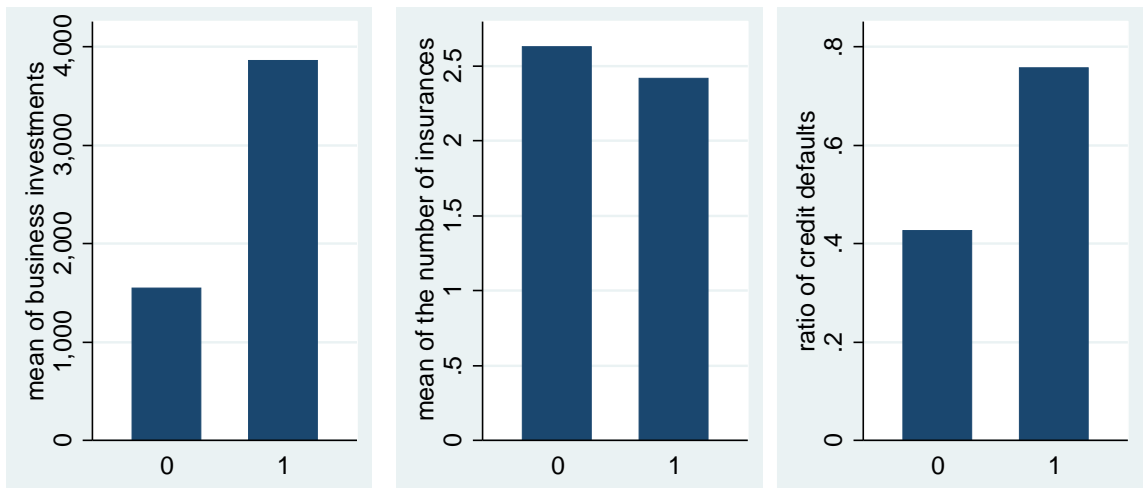

Notes: The first histogram refers to investments are measured in PPP US-dollar. The second histogram refers to the number of insurance contracts. The third histogram refers to the ratio of households with loan defaults or late repayments during the past 12 months relative to the number of participating households. 